ZOFIA BANET-FORNALOWA (Warszawa)

\title{
O ODPOWIEDZIALNOŚCI I MORALNYM ASPEKCIE BADAŃ HISTORYCZNYCH Uwagi na marginesie „odkryć” Zbigniewa Romaniuka
}

Jest sprawą niezmiernie kłopotliwą podjęcie polemiki z p. Zbigniewem Romaniukiem ze względu na niski poziom merytoryczny jak i formę publikacji, które zamieścił w „Studiach Podlaskich” w tomach XII z. 2002 r. i XIV z 2004.

Pierwszy artykuł pt.: Ludwik Zamenhof -- nieznane szczególy bialostockiego życiorysu został opublikowany w t. XII, na str. 291-300, a drugi pt.: Najtrudniej wytlumaczyć rzeczy oczywiste. W odpowiedzi na list P. L. Ch. Zaleskiego-Zamenhofa w t. XIV, na str. 119-125.

Kłopotliwość polemiki z tym, co opublikował Z. Romaniuk polega na tym, że autor wypowiada się arbitralnie w przedmiocie, do którego nie jest przygotowany. Po prostu nie zna literatury dotyczącej spraw, na temat których się jednoznacznie wypowiada. Z. Romaniuk daje tego świadectwo już na początku ww. pierwszego swojego artykułu (w przypisach str. 291), gdzie podaje „ważniejsze publikacje”, wg niego, dotyczące tematu. Rzecz w tym, że tylko niektóre $\mathrm{z}$ tych pozycji zasługują na miano „ważniejszych”. Niektóre stanowią publicystykę informacyjną, daleko odbiegającą od materiałów źródłowych, zawierające liczne błędy faktograficzne i w zakresie ocen.

Brak niestety najpoważniejszych pozycji opartych na rzetelnej i wszechstronnej bazie źródłowej. Chodzi w pierwszym rzędzie o dzieła Adolfa Holzhausa, w tym szczególnie pozycji Doktoro kaj lingvo Esperanto, Naftali Zwi Maimona La kaśita vivo de Zamenhof, Haliny Edelbaum Halina Dokumento pri la studentqj jaroj de L. L. Zamenhof, zbiór dokumentów dotyczących m.in. bezpośrednio lat z biografii L. Zamenhofa, o których pisze Z. Romaniuk, Itô Kanzi Plena Verkaro Zamenhofa. Dzieła tego ostatniego zawierają najpełniejszy zbiór źródeł do życia i twórczości Zamen- 
hofa i szerzej esperanta. Nie ma też wśród tych „ważniejszych publikacji” autobiograficznych pozycji samego twórcy esperanto, w tym najważniejszego Listu do Alfreda Michaux z $1905 r$., obejmującego również lata gimnazjalne, o których pisze w swoich artykułach Romaniuk. $\mathrm{Z}$ tego listu dowiadujemy się, że zarówno $\mathrm{w}$ gimnazjum białostockim jak i warszawskim „...był zawsze pierwszym uczniem w swojej klasie”. Bardzo dobre wyniki w nauce L. Zamenhofa - ucznia potwierdzają dokumenty znajdujące się w Halina Dokumento, pierwszy w tym dziele dokument dotyczy roku szkolnego $1873 / 74$ str. 10, jak i w szeregu innych. Należał też do najwybitniejszych studentów Wydziału Medycznego Uniwersytetu Moskiewskiego i Cesarskiego Uniwersytetu w Warszawie, i to również jest w tym dziele potwierdzone.

To tylko niektóre pozycje, które powinien znać każdy badacz jego życia, w szczególności ten, kto autorytatywnie wypowiada się na temat życia L. Zamenhofa i pretenduje do rewizji wszystkiego, co dotyczy niektórych okresów życia twórcy esperanto.

Z. Romaniuk szukając materiału do swojej pracy doktorskiej natknął się w archiwum grodzieńskim na notatkę Dyrektora Dyrekcji Szkół Białostockich dotyczącej nauki i sprawowania Lejzera Zamenhofa na krótko przed przeniesieniem się rodziny Zamenhofów do Warszawy w 1873 r., i podczas pierwszych lat 1873-75 kiedy rodzina mieszkała już w Warszawie, a 14-15-letni Zamenhof rzekomo został wtedy sam w Białymstoku, również na list rzekomo przez L. Zamenhofa napisany. Oba dokumenty są dla L. Zamenhofa, mówiąc najdelikatniej, bardzo nieprzychylne. Z. Romaniuk swoje odkrycia, bez ich weryfikacji, czym prędzej opublikował nie tylko w "Studiach Podlaskich”, ale też w „Kurierze Porannym” w dodatku „Magazyn”, w dziale "Historia” z dn. 10 stycznia 2003 i w innych czasopismach, w tym i esperanckich. Rozpowszechnił też swoje odkrycia na spotkaniach z białostockimi, i nie tylko, esperantystami, również w Internecie. Pochopność i rozmach z jakim Z. Romaniuk upowszechnil swoje „odkrycie” również zniechęcają do podjęcia $\mathrm{z}$ nim polemiki.

Dziwnym zbiegiem okoliczności te dokumenty zostały odnalezione niedługo po plebiscycie zorganizowanym przez znaczącą prasę białostocką, radio i telewizję również regionu Podlasia. W jej wyniku, twórca esperanto Ludwik Zamenhof - humanista, którego celem życia było działanie aby ludzie poprzez tolerancję i akceptację różnorodności podnosili jakość życia społeczeństw, a esperanto stało się nosicielem jego idei, czym szeroko w świecie rozsławił swoje rodzinne miasto Białystok, został uznany w ww. plebiscytach Najwybitniejszym Białostoczaninem, a także Podlasianinem XX wieku. 
Odnalezione przez Romaniuka dokumenty dotyczące lat 1873-1875, przedstawiające $w$ sposób bardzo negatywny L. Zamenhofa, nadawały się w jego opinii do „odbrązowienia” bohatera. Rzecz jasna, że te dokumenty, aby mogły służyć jako podstawa publikacji zanim ujrzą światło dzienne, należało koniecznie poddać wszechstronnej weryfikacji, zgodnej z kryteriami naukowymi. Rzecz jednak w tym, że Romaniuk nie zna literatury przedmiotu, jak wyżej powiedziano, a jest ona obszerna. Nie zna też źródeł, które w wypadku rodziny Zamenhofów są zapisane w językach: hebrajskim, jidisz, rosyjskim, polskim, w innych językach europejskich i bardzo obszernie w języku esperanto. Znajdują się one w wielu archiwach ogólnych ziomkostw, w czasopismach różnych krajów, w księgach cmentarnych, w literaturze wspomnieniowej, cytowane są w wielu różnorodnych opracowaniach monograficznych i biografiach.

"Odkrywca" nie spełnił więc zasadniczego obowiązku, do którego jest zobligowany badacz, a obowiązek ten odnosi się nie tylko gdy pisze się o ludziach o światowym rozgłosie, ale dotyczyć powinien każdego człowieka, o którym wypowiada się historyk. Romaniuk nie wziął też pod uwagę moralnego aspektu swojego działania, kiedy w sposób pospieszny, na podstawie tylko dwóch dokumentów z jednego źródła opublikował swój artykuł, który jednoznacznie zniesławia L. Zamenhofa, jego ojca Marka Zamenhofa, jest też niepochlebny ogólnie dla rodziny.

Z późniejszych publikacji wynika, że mimo iż istnieją inne, całkowicie wiarygodne dokumenty przedstawione Romaniukowi, a które zadają kłam obrazowi przedstawionemu w "Studiach Podlaskich” t. XII jak i wyżej wymienionemu artykułowi w „Kurierze Porannym”, który, jest na to w pełni podstawa, można określić jako paszkwil, nie potrafi się z tej sprawy godnie i jednoznacznie wycofać. Ratując się, brnie dalej nowymi „odkryciami”, opiniami, nie znajdującymi potwierdzenia w realnych faktach. Nie stroni też od półprawd, aby po kompromitacji nie został uznany za niepoprawnego amatora w sztuce.

Nie trzeba dużo pisać o tym jak publikacja w „Studiach Podlaskich”, a w szczególności artykuł w „Kurierze Porannym”, niesłychanie obraźliwy w tonie, pełen drastycznych epitetów, zaszokował szeroką opinię społeczną, w szczególności esperantystów i białostoczan. W tym miejscu warto zaznaczyć, że „Kurier Poranny” ma stosunkowo duży nakład, co potęguje szkodliwość oddziaływania tej publikacji. Piszę w tym miejscu o artykule w „Kurierze Porannyın” gdyż jest skróconą i przeredagowaną wersją publikacji zamieszczoną wcześniej w „Studiach Podlaskich”. Również inny art. Z. Romaniuka zatytułowany Nieznany Zamenhof jest skróconą wersją tej 
publikacji. Z wypowiedzi Romaniuka w jego drugim artykule zamieszczonym w „Studiach Podlaskich” (t. XIV-2004, str. 121) wynika, że środowisko naukowe Białegostoku nie zareagowało na jego odkrycia.

Białostoccy esperantyści (nie wiem czy wszyscy...) w swojej naiwności $\mathrm{i}$, jasno to trzeba powiedzieć, niedokształceniu w zakresie esperanta, istniejącej bibliografii i ufni w odpowiedzialność badacza przeszłości, choć zapewne z zażenowaniem przyjęli odkrycia Romaniuka bezkrytycznie i w konsekwencji pomogli mu w ich upowszechnieniu. Niestety, o tej publikacji ani kierownictwo Białostockiego Towarzystwa Esperantystów, ani Fondumo Zamenhof nie poinformowało historyków badających historię ruchu esperanckiego korzystających szeroko ze źródeł. Nie zadbało aby uzyskać ich opinię w tym względzie. Nie został też poinformowany wnuk twórcy esperanta dr L. C. Zaleski-Zamenhof. W tym miejscu warto zaznaczyć, że jest on bardzo związany $\mathrm{z}$ białostockim środowiskiem esperanckim i byłoby rzeczą ważną, aby informacja o publikacji jednoznacznie zniesławiająca jego dziadka i szerzej jego rodzinę, niezwłocznie do niego dotarła. Dałoby mu to możliwość szybkiego zareagowania i być może zınniejszenia zakresu upowszechnienia tych pseudonaukowych rewelacji.

Ja dowiedziałam się o publikacji Romaniuka w „Kurierze Porannym” kilka tygodni po jej ukazaniu się od esperantystki z Bielska-Białej, zaszokowanej zarówno treścią jak i formą prezentacji. Określiła go ona jednoznacznie jako paszkwil. Przesyłając mi tę wiadomość wyraziła przekonanie, że ja skutecznie zareaguję. I tak się też stało. Niezwłocznie wysłałam przewodniczącej BES - E. Karczewskiej i przewodniczącemu Fondumo Zamenhof - J. Parzyszkowi kopię dokumentów znajdujących się w źródłowym dziele Halina Dokumento. Nazwa pochodzi od imienia Haliny Edelbaum, esperantystki z Warszawy, która podczas kilkuletnich badań w okresie międzywojennyın w obszernym tomie zgromadziła dokumentację dotyczącą lat gimnazjalnych i studiów L. Zamenhofa, w sumie 123 dokumenty. Są to kopie oryginalnych świadectw, wyników egzaminów gimnazjalnych i zaliczeń studenckich, zaliczeń egzaminów w poszczególnych semestrach, uchwały Rad Pedagogicznych przyznających mu medale za wybitne osiągnięcia w nauce i wzorowe zachowanie, decyzje o zwolnieniu $\mathrm{z}$ części opłat za naukę i szereg innych. Dokumenty pomieszczone w tym dziele obejmują lata 1873 - od chwili rozpoczęcia nauki w Warszawskim Drugim Męskim Gimnazjum, do 1885 roku - otrzymania Dyplomu Lekarza w Cesarskim Uniwersytecie w Warszawie.

Warto w tym miejscu zaznaczyć, że publikacja Romaniuka zniesławiająca ucznia L. Zamenhofa dotyczy lat $1873-1875$. Z kopii oryginalnych do- 
kumentów w dziele H. Edelbaum jasno wynika, że był on, jak wyżej powiedziane, począwszy od roku szkolnego 1873/74 pochłonięty nauką, odznaczał się ponadto wzorowym zachowaniem, co wysoko oceniła Rada Pedagogiczna i Dyrekcja ww. Gimnazjum. H. Edelbaum po uzyskaniu, nie bez przeszkód, zezwolenia odnośnych władz na badania zasobów archiwalnych swoje dzieło, $\mathrm{z}$ wielką troską i pietyzmem przygotowane, przesłała swojemu japoískiemu korespondentowi Juntaro Iŭasita w 1934 roku z nadzieją, że on je wyda, gdyż interesował się biografią L. Zamenhofa. Trudny okres drugiej połowy lat 30. w Japonii, wojna, jak równiez lata powojenne nie sprzyjały temu celowi. Dzieło zostało wydane dopiero w roku 1977. Halina Edelbaum zginęła w okresie holokaustu. Ale jej praca przetrwała w formie niezwykle wartościowego dzieła, które służy dokumentowaniu prawdy historycznej.

Wszystko więc, co zamieścil Romaniuk w swojej publikac.ji w t. XII „Studiów Podlaskich" str. 298-299, jest kompletnie niezgodne z prawdą. I nie dotychczasową biografię Zamenhofa trzeba między bajki włożyć, jak to Romaniuk radzi, ale tę, którą on zaprezentował należy odrzucić jako „czarną legendę".

Podsumowując rzekome niesłychane wyczyny 14-15-letniego L. Zamenhofa Romaniuk wyraża opinię, iż dobrze się stało, że carski urzędnik nie wprawił w czyn zamysłów i próśb Zamenhofa, bo „kto wie czy Ludwik pochłonięty niesłychanie rozbudowaną carską biurokracją miałby wówczas czas na dzieło swojego życia - ESPERANTO” ( Studia Podlaskie”, t. XII, str. 299). I w przypisie 19. do słowa esperanto Romaniuk daje następującą uwagę: „Język esperanto był wykorzystywany i do celów politycznych. Dzialacze komunistyczni w latach 50. i 60 . XX w. dostrzegali w nim przewagę dla języka angielskiego uznawanego "w świecie zachodnim» za międzynarodowy. W Polsce nawet radio nadawało audycje w języku esperanto". Myślę że tę opinię o języku międzynarodowym esperanto nie można uznać ani za trafną, ani przychylną... Do wiadomości autora podaję, że audycje radiowe w języku esperanto nadawano i nadal się nadaje w kilku krajach świata. Od wielu lat nadawane są też w Radio-Vatikano.

Czerpiąc z dokumentacji zawartej w Halina Dokummento pragnę w tym miejscu ustosunkować się do dygresji Romaniuka dotyczącej L. Zamenhofa jako lekarza. Jest on pewny, że dr L. Zamenhof nie był dobrym okulistą. Argumentem dla Romaniuka jest fakt, że nie był on w stanie przez pewien okres zapewnić rodzinie utrzymania. W tej sprawie chciałam zwrócić uwagę na dokumenty znajdujące się $\mathrm{w}$ ww. dziele. Wynika z niego, że L. Zamenhof od początku studiów brał pod uwagę ewentualność specjalizacji w zakresie okulistyki. Uczęszczał na wykłady $\mathrm{z}$ oftalmologii zarówno na Uniwersyte- 
cie Moskiewskim jak i Warszawskim i zaliczał egzaminy $\mathrm{z}$ tego przedmiotu z najwyższymi notami: 5. Po studiach praktykował u słynnego warszawskiego oftalmologa i społecznika dr. Zygmunta Kramsztyka. Wzorując się na nim leczył też część pacjentów za darmo. Dokształcał się też w klinikach zagranicznych. Istnieją wypowiedzi, wspomnienia pacjentów świadczące, że był dobrym lekarzem. Serdeczne i empatyczne podejście do nich budziło zaufanie i ułatwiało leczenie. Brak sukcesów finansowych nie jest argumentem właściwym. Przydatność zawodowa, a jest na to wiele przykładów, nie zawsze daje się przełożyć na dochody. Zapewne zaangażowanie w rozwój języka esperanto i idei, których nosicielem jest ten język nie sprzyjały pełnej koncentracji w zawodzie. $\mathrm{Z}$ drugiej jednak strony należy wziąć pod uwagę sytuację ekonomiczną i społeczną w Imperium Rosyjskim w czasach dr Zamenhofa aby zrozumieć, że nie sprzyjała ona leczeniu szerokich rzesz pacjentów przez specjalistów. W późniejszym jednak okresie dr Zamenhof miał ich coraz więcej. Sam o tym pisał. Stąd nie na miejscu jest uwaga Romaniuka, że nie był taki biedny jak go się przedstawia, chcąc przez to niejako podkreślić, że i w tym względzie występuje zafałszowanie jego biografii. W tym miejscu uwaga, że chociaż jego obecność na Międzynarodowych Kongresach Esperanckich była niezwykle potrzebna i pożądana, stąd wynikały często propozycje ze strony organizatorów pokrywania jego kosztów z tym związanych. Nigdy się na to nie godził. Zawsze pokrywał swoje i żony koszty. Zresztą również jego bracia Feliks i Leon, którzy byli bardzo zaangażowani w ruchu esperanckim i wnieśli duży wkład w rozwój organizacyjny i wzbogacenie esperanckiej kultury, w tym poprzez esperanto promując kulturę polską podobnie postępowali. Tej normy przestrzegały także dzieci twórcy esperanto.

A teraz zdań kilka dotyczących innych spraw. Z. Romaniuk w swojej pasji odkrywania chcial, jak by to powiedzieć, za jednym zamachem przedstawić nowe... fakty i o innych członkach rodziny Zamenhofa.

W 1999 roku w Tykocinie odsłonięto tablicę ku czci ojca twórcy esperanto Marka Zamenhofa - człowieka wszechstronnie oświeconego, którym szczyciłoby się każde miasto. Ten fakt zwrócił szczególną uwagę Romaniuka na tę postać. Rozpoczął więc swoje poszukiwania - badania w Tykocinie i Białymstoku. Nie znalazł metryki urodzenia Marka w Tykocinie, ani też dostatecznych śladów dotyczących okresu osiedlenia się i życia jego rodziny w tym mieście. To mu wystarczyło aby zanegować wiarygodność jego urodzenia $\mathrm{w}$ Tykocinie, a zatem podstawę uczczenia jego pamięci $\mathrm{w}$ tym mieście. Romaniuk nie ma wątpliwości, więc nie podejmuje dalszych poszukiwań, a takie możliwości istnieją, jako że źródła dotyczące żydowskiej 
ludności żyjącej ongiś na tych ziemiach są obfite i różnorodne, chociaż rozproszone w różnych częściach świata. Można też znaleźć je w archiwach Królestwa Polskiego i w innych częściach dawnej Rzeczpospolitej. Niezmiernie ważne dla każdego badacza dziejów żydowskiej ludności Białegostoku jest dwutomowe dzieło A. S. Herszberga Pinkas Bialystok (Kronika Bialegosto$k u$ ) wydane pośmiertnie w 1949-1950 r. Autor zginął w getcie białostockim. Według N. Z. Maimona, jednego z najwybitniejszych zamenhofologów, dzieło to oparte jest na głębokich studiach źródłowych autora. Najpoważniejsze dzieła związane $\mathrm{z}$ tym regionem, a szczególnie $\mathrm{z}$ Białemstokiem, bazują na głębokiej wiedzy w nim zawartej. Podobne opinie wyrażają inni badacze i instytucje jak np., Białostockie Centrum w Nowym Jorku wydające przez wiele lat czasopismo „Bjalistoker Sztime” („Głos Białegostoku”). Znajdują się m.in. w nekrologach prasy w języku hebrajskim „HaCefira” czy rosyjsko-żydowskiej „Razsvet” i innych. Również w prasie esperanckiej, m.in. przesłanym przeze mnie do Białegostoku „Pola Esperantisto” ze stycznia 1908 roku, gdzie jako miejsce urodzenia figuruje Tykocin. To wszystko dla odkrywcy Romaniuka jest nieważne. Obszerny nekrolog z „Pola Esperantisto" Romaniuk kwestionuje, bo znajdują się tu „inne nieścisłości”. Prawda, że sformułowanie „po ukończeniu studiów” nie jest precyzyjne, jako że Marek był niezwykle utalentowanym samoukiem i studiów w trybie normalnym nie ukończył. Nie znaczy to jednak aby istniała podstawa zakwestionowania prawdziwości jego miejsca urodzenia tu zamieszczonego.

Nekrolog sygnowany jest literami Am. Jest to skrót imienia Adama Zakrzewskiego, wybitnego uczonego, ekonomisty, statystyka, jednego z pierwszych badaczy światowego i polskiego ruchu esperanckiego, członka Komitetu Redakcyjnego „Pola Esperantisto”, w którym prowadził Kronikę. Nekrolog o Marku Zamenhofie ukazał się w styczniowym numerze Kroniki jako jej pierwsza pozycja. Osoba jej autora gwarantuje adekwatność faktów z życia ojca twórcy esperanto. Należy dodać, że redaktorem „Pola Esperantisto” był w tym czasie dr Leon Zamenhof, syn zmarłego, a konsultantem Komitetu Redakcyjnego „Pola Esperantisto” był wówczas dr Ludwik Zamenhof. Nasuwa się więc pytanie jaki przyświecałby im cel, aby w tej kwestii wprowadzać opinię publiczną w błąd.

Istnieją w tym wypadku inne możliwości dociekania prawdy, np. w rosyjskich urzędowych dokumentach. Marek Zamenhof był przecież urzędnikiem państwowym i nauczycielem rosyjskich szkół państwowych, wobec czego podstawowe dane personalne zapewne w jego dokumentach się znajdują. Istnieją źródła w ziomkostwach, księgi cmentarne, literatura pamiętnikarska i inne dokumenty. Myślę, że również odnalezienie aktu urodzenia świadczą- 
ce, że M. Zamenhof urodzil się w innej miejscowości dałoby Romaniukowi podstawę do tak jednoznacznego poglądu w tej kwestii.

Z. Romaniuk nie potrzebuje się jednak upewniać. On wie. Nie znalazł w Tykocinie poszukiwanego aktu urodzenia, to dla niego jednoznaczne, że Marek Zamenhof się w tym mieście nie urodził. Wątpliwości nie budzi nawet fakt - jak sam stwierdza - że w swoich badaniach natrafił na duże luki w zapisach urzędowych. Podobnie pewny jest i w innych sprawach dotyczących Marka Zamenhofa. Policja carska podejrzewała go, że on, a może jego ojciec, pisze donosy. Romaniuk jest pewien. Jest też pewien, że tym donosom zawdzięczał awans, przeniesienie do Warszawy i pracę w szkołach państwowych. Tak sarno jak wie, że szkoła którą w Białymstoku prowadził „nie należała do najlepszych”. Skąd ta wiedza, na podstawie jakich badań? Istnieją liczne dowody świadczące o tym, że M. Zamenhof już w latach młodzieńczych gdy udzielał korepetycji odznaczał się niezwykłymi zdolnościami. $\mathrm{Na}$ ten temat istnieje m.in. wspomnienie żydowskiego pisarza Jehiela Pinesa (ps. Michał), zamieszkalego w owym czasie w Różanie Grodzieńskiej, w jego dziele Wybór Pism Pinesa wydanych w latach 1934-39. Przyszly pisarz mial wtedy 7 lat, a Marek 12 i uczył go języka niemieckiego. Pines $\mathrm{z}$ wdzięcznością wspomina swojego korepetytora, dzięki któremu mógł zagłębić się w dzieła najwybitniejszych pisarzy niemieckich. Uznanie jakim cieszył się jako nauczyciel w gimnazjum i lektor Instytutu Weterynarii w Warszawie mogą raczej świadczyć na korzyść jego wcześniejszej szkoły w Białymstoku.

Czytelnik „odkryć” Romaniuka ma wrażenie, że przedstawiając ojca przyszłego twórcy esperanta $\mathrm{w}$ jednoznacznie negatywnym świetle autor chce czytelników przygotować, zmniejszyć niejako szok wywołany obrazem jego „marnotrawnego syna”. No bo skoro tak wątpliwej wartości moralnej był ojciec, to jaki ma być jego pierworodny...

Należało mieć nadzieję, że to co Romaniuk napisał o L. Zamenhofie, a co okazało się kompletnym fałszerstwem, może skłoni autora do pogłębionych badań nad biografią jego ojca i przedstawienia go takim. jakim rzeczywiście był. A był człowiekiem wyjątkowo wszechstronnie wykształconym, szanowanym, ponadto dobrym ojcem rodziny. Świadczy o tym m.in. dbałość o wykształcenie dzieci, w tym i córek, co w ówczesnym okresie nie było zjawiskiem powszechnym.

Niestety Romaniuk nie przyznaje się do błędów w badaniach i ich prezentacji. Na uwagi dr. L. C. Zaleskiego-Zamenhofa o niekonsekwencjach i brakach w przedstawionych „odkryciach” po prostu blefuje, mataczy i niejednokrotnie mija się z prawdą. Podaję tylko kilka przykładów w tej materii. W publikacji zamieszczonej w „Studiach Podlaskich” t. XII na str. 295-296 
Romaniuk dokonuje „odkrycia” powszechnie już znanego pisząc: „zadziwiające jest jak mało faktów genealogicznych ustalili biografowie o rodzinie Zamenhofów". I tu odkrywa. że dziadek Zamenhofa - Fajwel oprócz Mordche (Marka) miał też drugiego syna, którego, jak wynika z tekstu, on niejako odkrywa. I tu Romaniuk mija się $\mathrm{z}$ prawdą, bo w wielu źródłach jest ten fakt odnotowany. Nie wymienia tu natomiast trzech córek Fajwla. Zaś w artykule Nieznany Zamenhof w podrozdziale zatytułowanym Rodzina, pisząc o Fajwlu - ojcu Marka Zamenhofa, nadmienia: „miał on co najmniej dwóch synów, a pewnie też i inne dzieci". I tu podaje imiona dwóch synów: Mordko (późniejszy Marek) i drugi syn Josel-Wolf (znany później jako Jozef). Na uwagę dr. Zaleskiego-Zamenhofa dlaczego nie wymienił innych dzieci Fajwla, konkretnie trzech córek („Studia Podlaskie” 2004, t. XIV, str. 109), pisze w swojej odpowiedzi „nie napisałem o siostrach Marka, bo to uczyniła już p. Z. Banet-Fornalowa" (ten sam tom, str. 109). Dziwne, czy nie. Najpierw stwierdza, że Fajwel oprócz wymienionych dwóch synów miał „pewnie też i inne dzieci". Czyli nie wie dokładnie, a w innym artykule już wie, ale tego nie napisal, bo to zrobiła p. Z. Banet-Fornalowa. W niesłychane zamieszanie wprowadza Romaniuk czytelnika odnośnie dzieci Josia (Jozefa), brata Marka. W artykule zamieszczonym w „Studiach Podlaskich” (t. XII, 2002 r., str. 295-296) jest napisane, że miał kilkoro dzieci. Jedno po dziadku nosiło imię Fajwel vel Fabian, a inne to Frejda, zwana też Fryderyką, Jankiel „...a z pewnością też Rebeka i Salomon”. Imię Lejzer nie figuruje. W artykule opublikowanym w „Kurierze Porannym” informuje: „W Białymstoku urodziło mu się kilkoro dzieci. Jedno nosiło po dziadku imię Fajwel oraz dodatkowo Fabian, a ponadto byli też Jankiel, Salomon i Rachela". Brak jakiejkolwiek wzmianki o Lejzerze. W wyżej już wspomnianym artykule pt. Nieznany Zamenhof Romaniuk wymieniając dzieci Josla wspomina dwóch jego synów, którzy tu także występują pod imieniem Fajwel (jeden zmarł, więc drugiemu też nadał imię Fajwel), inny syn nazywał się Jankiel. Tu nie wymienia się już ani Salomona, ani Racheli, ani Frejdy ani Rebeki i tak jak w uprzednich źródłach zupełnie brak syna imieniem Lejzer, który później „po dokładniejszej kwerendzie” okazał się tym nicponiem i wiarołomcą. Ciekawe, co skłoniło Romaniuka do „dokładniejszej kwerendy" i dlaczego zrobił to już po opublikowaniu paszkwilu zniesławiającego L. Zamenhofa, późniejszego twórcę esperanto.

Inny przykład. Romaniuk pisze, że rodzina Zamenhofów była w Białymstoku nieznana. Z kontekstu wynika, że nieznacząca. Ma o tym świadczyć mylnie zapisywane w niektórych rosyjskich dokumentach, m.in. w świadectwie urodzenia L. Zamenhofa, ich nazwisko Zamenow. Czyżby uszło uwadze 
Romaniuka, że w rosyjskim alfabecie nie ma litery „h”. Przeoczenie tego „drobiazgu" ma swój skutek i w innym jego „odkryciu”, dotyczy liczby potomstwa Marka i Rozalii Zamenhofów. Według wszystkich znanych mi źródeł mieli oni dziewięcioro dzieci. Romaniuk podaje jedenaścioro. Błąd bierze się stąd, że wymienia on Hersza (Henryka) i Grzegorza jako dwie postaci, a jest to ta sama osoba. Po prostu Hersz figuruje w rosyjskich dokumentach jako Grigorij, m.in. w Halina Dokumento, jako że do tego samego gimnazjum uczęszczało pięciu Zamenhofów: trzech braci L. Zamenhofa i jego syn Adam. Henryk też często podpisywał swoje artykuły w Kobiecie, awangardowym, fachowym czasopiśmie, które przez kilka lat wydawał pod imieniem Grzegorz. O Minie w żadnym źródle dotyczącym rodzeístwa L. Zainenhofa się nie wspomina. Czy nie lepiej dać wiarę samyın Zamenhofom i ich wiarygodnym biografom, niż - jak wynika $\mathrm{z}$ artykułów Romaniuka - niedokładnyın zapisom urzędników rosyjskich w Białymstoku czy Grodnie. A w ogóle odnośnie dat urodzin i śmierci rodzeństwa L. Zamenhofa ( Studia Podlaskie” 2004, t. XIV, str. 123) roi się od błędów. Ale jest to temat na oddzielną rozprawę.

W późniejszych badaniach Romaniuk w swoich sugestiach posuwa się znów znacznie dalej, niż jest w stanie udowodnić w sprawie życia i działalności dr. L. Zamenhofa. Fałszerstwem okazal się wizerunek dotyczący jego okresu uczniowskiego, penetruje więc Romaniuk okres późniejszy, grodzieíski. W sprawie służby zatrudnionej u małżeístwa Zamenhofów stwierdza, $\dot{z e}$ nie miał złych intencji. Jednakowoż komentarz do tej informacji świadczy o czymś innym, gdyż w tym miejscu zauważa, iż z tego wynika, że nie był taki biedny jak się go przedstawia... Czy nie było też intencji zasugerowania czegoś niemoralnego w postępowaniu Zainenhofa, gdy Romaniuk poinformował podczas prelekcji w Białostockim Towarzystwie Esperantystów 13 grudnia 2003, podaję informację za artykułem Katarzyny Połeć Urodziny Zamenhofa ("Gazeta Wyborcza” z 15 grudnia 2003 r., wydanie białostockie), że „Podczas swego "etapu " grodzieńskiego, L. Zamenhof udzielał się także jako sędzia przysięgły i podobno podczas procesów wyróżniał się szczególną "pryncypialnością i surowością«". Romaniuk nie wyjaśnił na czym polegała ta „szczególna pryncypialność i surowość”. W czyim była interesie. Nie trzeba być odkrywcą żeby się domyśleć, że to sformułowanie, w świetle innych „odkryć" tego autora, nie ma na celu nobilitacji dr. L. Zamenhofa. I tylko w koíicowej części prelekcji Romaniuk odkrył sensac.ję, jako wynik dalszych swoich badań. Sprowadza się ona do tego, że Lejzer Zamenhof - przyszły twórca esperanta, miał w Białymstoku swojego imiennika, ucznia tej samej szkoły, niewiele od niego młodszego. Ten drugi Lejzer był jego kuzynem - 
bratem stryjecznym, synem .Josia Zamenhofa. Ponownie cytuję za K. Połeć: „Jestem teraz skłonny przyznać, że odkryte w Grodnie dokumenty dotyczą jednak tego drugiego Lejzera - stwierdził Romaniuk - Tym samym historia Zamenhofa zyskała nową barwną postać z jego bliższego otoczenia".

Nieprawdopodobne, ale po tym oświadczeniu nie nastąpiły żadne słowa wskazujące na to, że Z. Romaniuk ma jakiekolwiek poczucie winy za zniesławienie dr. Ludwika Zamenhofa i jego rodziny. Za obniżenie rangi nauki jako wynik pochopności w publikac.ji badań i warsztatowej niekompetencji. Artykuł K. Połeć przetlumaczył na esperanto J. Parzyszek. Został on opublikowany w „La Ondo de Esperanto” w lutowyın numerze 2004 r. Ponadto rozpowszechniony przez Internet. $\mathrm{Na}$ tyın smutnym stwierdzeniu można by zakończyć te uwagi gdyby jednak te niezgodne z prawdą, a więc i niezwykle szkodliwe odkrycia nie były tak szeroko rozpowszechniane.

Należy wspomnieć, że powiadomiony przeze mnie wnuk twórcy esperanto dr L. C. Zaleski-Zamenhof zareagował interwencją w środowisku białostockich esperantystów, którzy, jak wyżej wspomniałan, wykazali się niestety brakiem znajomości podstawowych źródeł biografii Zamenhofa dotyczących ruchu esperanckiego. Stąd nieodpowiedzialność w upowszechnieniu pseudonaukowych odkryć Romaniuka. Dr Zaleski-Zamenłıof skierował też list do prof. Michała Gnatowskiego - Przewodniczącego Rady Redakcyjnej „Studiów Podlaskich", które udostępniły swoje lamy Z. Romaniukowi do opublikowania w tomach XII z 2002 i XIV z 2004 wyników jego badań.

List ten został udostępniony $\mathrm{Z}$. Romaniukowi przed opublikowaniem listu dr. Zaleskiego-Zamenhofa, co dało mu możliwość natychmiastowej odpowiedzi. Oba teksty ukazały się w t. XIV „Studiów Podlaskich”.

Nie jest moim zadaniem streszczanie, czy też szczegółowe ustosunkowanie się do tych dokumentów. Pragnę jednak zaznaczyć, że list dr. Zaleskiego-Zamenhofa cechuje rzeczowość i poprawność w formie. Autor stara się argumentować zgodnie z posiadaną wiedzą. Odpierać pomówienia i insynuacje na podstawie dokumentów. Ma się wrażenie, iż wierzy, że Romaniuk jest w stanie przemyśleć sprawy i dać tego dowód przez wycofanie się z fałszerstw i nieudowodnionych domysłów na temat L. Zamenhofa i jego rodziny rozpowszechnionych w kilku publikacjach. Niestety, jego odpowiedź o znamiennym dla tego autora mentorskim tytule Najtrudniej wytlumaczyć rzeczy oczywiste tej nadziei nie spełnia. Romaniuk stwierdza w tej odpowiedzi, że nie znalazł w liście dr. Zaleskiego-Zamenhofa konstruktywnej krytyki, a tylko emocje i inwektywy, do których się nie będzie odnosil. Nadal podtrzymuje, że spełnił ważne zadanie naukowe. Tę opinię wyraził w stwierdzeniu „Podtrzymuję swoje zdanie, że niestety dotychczasowi biografowie nie wy- 
korzystali podstawowej bazy źródłowej do ustalenia białostockiego rozdziału Zamenhofów, zamykając się w kręgu znanej od lat literatury bez próby jej poszerzenia” („Studia Podlaskie”, t. XIV, str. 119).

W tym miejscu warto zauważyć, że Z. Romaniuk w dążeniu do „poszerzenia" osiągnął rezultat fatalny. Popełnił mianowicie paszkwil przeciwko dr. Ludwikowi Zamenhofowi, z którego, acz niezbyt odważnie, jednakowoż musiał się wycofać, a szkody jakie wyrządził tym „poszerzeniem” są $\mathrm{z}$ każdego punktu widzenia ogromne. Z. Romaniuk w odpowiedzi na wyżej wspomniany list stwierdza, że czuł się w obowiązku dokonać sprostowania wcześniej podanych informacji i tu podaje gdzie je zamieścil. Niestety zasięg dokonanych sprostowań jest daleko niedostateczny w stosunku do rozmiarów rozpowszechnienia, uwłaczających imieniu Ludwika Zamenhofa i jego bliskich, fałszerstw i pomówień przez ich autora nazwanych „informacjami”. Czy nie należało w pierwszym rzędzie nie czekając na list dr. Zaleskiego-Zamenhofa, niezwłocznie, w sposób poważny i jednoznaczny tekst samokrytyczny zamieścić w „Studiach Podlaskich”, „Kurierze Porannym” i innych środkach przekazu, których redakcje, zapewne nieświadome pochopności publikowania niesprawdzonych odkryć udzieliły mu swoich łam.

Należy wierzyć, że środowisko naukowe Białegostoku potrafi mu to dosadnie wytlumaczyć. Jednakowoż fałszerstwa, pomówienia, półprawdy, które poszły szeroko $\mathrm{w}$ świat $\mathrm{z}$ pewnością znajdą w niejednej publikacji odbicie, jako że trudno poza wąską grupą zainteresowanych objąć całokształt tego pseudonaukowego problemu.

Nie jest sprawą jasną, czy autentyczne przekonanie o wartości swoich badań, czy też fałszywa ambicja każą Romaniukowi upierać się przy tej ewidentnej kompromitacji. Dowodem tego jest wyszczególnienie w odpowiedzi na list dr. L. C. Zaleskiego-Zamenhofa osiągnięć w wyżej omawianej problematyce. Wśród nich wylicza ustalenia dotyczące ilości rodzeństwa L. Zamenhofa, ich dat urodzin i śmierci. Jak wyżej wspomniałam, roi się w tej informacji od błędów. Daty wcześniejszego powrotu Zamenhofów z Grodna do Warszawy nie musiał odkrywać, gdyż ta data - 1897 r. znajduje się we wspomnianym liście do L. Zamenhofa do A. Michaux i w wielu innych źródlach esperanckich, m.in. w książeczce Andre Cherpieloda Zamenhof Datoj Faktoj Lokoj. O chaosie w opisaniu bocznej linii Josla - stryja Zamenhofa, wyżej wzmiankowałam. Zostają jako odkrycia: znalezienie aktu zgonu Fajwla - Fabiana Zamenhofa. Ustalenie, że Marek Zamenhof miał drugi zawód - buchaltera. Ustalenie też jaką szkołę matka L. Zamenhofa ukończyła. Data zapisania rodziny Zamenhofów do ksiąg gminy żydowskiej w Tykocinie. Nie wiem czemu nie dodaje, że bardzo pracowal nad ustaleniem żydowskich 
imion Zamenhofów, choć to nie było tajemnicą i znajduje odzwierciedlenie w licznych źródłach i opracowaniach.

Zakładając, że są to informacje ścisłe zostawiam ocenie czytelników, a przede wszystkim historyków ustalenie w jakiej proporcji zostają te odkrycia Z. Romaniuka wobec szkód jakie wyrządził rodzinie Zamenhofów, bezpodstawnie zniesławiając „Najwybitniejszego Białostoczanina i Podlasianina XX wieku", rzucając ponadto cień nieudowodnionymi twierdzeniami na jego ojca, i nie tylko. Ujmę jaką przyniósł nauce. $W$ tym miejscu uwaga. Będąc na miejscu Romaniuka i czerpiąc wnioski $\mathrm{z}$ fatalnej wpadki dotyczącej pierwszego Lejzera nie byłabym pewna co do tego drugiego. Może i w tym względzie należałoby wszechstronnie zweryfikować źródła.

Na zakończenie kilka uwag natury ogólnej. Z. Romaniuk w swojej odpowiedzi dr. Zaleskiemu-Zamenhofowi stwierdza, nie bez satysfakcji, że wyniki jego badań zostały dobrze, a nawet entuzjastycznie przyjęte przez esperantystów białostockich i nie tylko, że poddał je szerokiej weryfikacji także historykom. I „ani historycy, ani esperantyści nie byli w stanie dowodowo zaprzeczyć ustaleniom” („Studia Podlaskie” 2004, t. XIV, str. 121). Jest to zaskakujący argument. Czyżby Romaniuk spodziewał się, że białostoccy esperantyści zaprzeczą „dowodowo” jego ustaleniom. Czy spodziewał się, że białostoccy historycy zajmując się badaniami w zakresie innych dziedzin mogą tego dokonać...

Nasuwa się pytanie, dlaczego autor nie próbował skonsultować swoich „niezwykłych odkryć" $\mathrm{z}$ historykami, którzy badają ruch esperancki i publikują na ten temat prace oparte na szerokiej bazie źródłowej. Czy nie należy określić co najmniej jako nielojalność, że Romaniuk nie wspomnial, że weryfikacja jego odkrycia dotycząca L. Zamenhofa- ucznia przyszła właśnie z tej strony... Wyżej wspomniałam, że po zapoznaniu się z artykułem w „Kurierze Porannym" niezwłocznie wysłałam działaczom esperanckim w Białymstoku absolutnie wiarygodne dokumenty, całkrwicie obalające insynuacje zawarte $\mathrm{w}$ tym artykule. Poradziłam też aby nie wdając się $\mathrm{w}$ polemikę $\mathrm{z}$ jego autorem przedstawić redakcji „Studiów Podlaskich” i „Kuriera Porannego” powyższe dokumenty. Niestety, esperantyści tego nie uczynili. Jednakowoż jak dowiedziałam się od J. Parzyszka - zapoznali Romaniuka z nimi. Mam prawo przypuszczać, że zapoznanie się przez niego z tymi autentycznymi i bezdyskusyjnie pewnymi dokumentami stało się podstawą dalszych jego badań i „kwerendy”. W konsekwencji wycofania się z pseudonaukowych publikacji.

Chcąc zapobiec rozpowszechnianiu nowych a niezweryfikowanych „odkryć" Romaniuka udzieliłam w lutym 2004 wywiadu dr. Giorgio Silferowi 
w Internecie. Powyższy wywiad ukazał się tėz w „Heroldo dc Esperanto” w numerze marcowym 2004 r. Byłam gotowa przyjechać do Białegostoku aby na miejscu ustosunkować się do tej sprawy. Nie doszło do tego, nie z mojej winy. Nie jest więc prawdziwe stwierdzenie Romaniuka, że historycy nie zareagowali. Nie zareagowali ci, którzy nie znają problematyki, ani też ci, którzy ją znają, ale nie znają języka polskiego, co uniemożliwia zapoznanie się z publikacjami Z. Romaniuka. Ja zareagowałam. Podkreślam to nie tytułem przypisywania sobie zasług, bo to był mój obowiązek. Interwencja była skuteczna. Romaniuk wycofał się ze swoich odkryć. Z. Romaniuk wielokrotnie w swoich tekstach podkreśla, że esperantyści, rozmiłowani w swoim mistrzu, powtarzają ciągle utarte poglądy. Daje on w ten sposób wyraz swojej ignorancji $w$ tej dziedzinie. Niesposób w tym miejscu rozwinąć ten temat, ale wspomnieć należy, że historiografia esperancka ciągle się rozwija. Szczególnie duże postępy poczyniła po II wojnie światowej. Dokonała tego grupa zamenhofologów, wszechstronnie wykształcona, spośród której część zna wszystkie języki, w których znajdują się materiały źródłowe dotyczące przedmiotu ich badań. W ostatnich dziesięcioleciach powstało wiele wartościowych, źródłowo udokumentowanych dzieł. Podjęto w nich problematykę wcześniej z różnych względów pomijaną, a dotyczącą zarówno aspektów i kierunków ruchu esperanckiego, działalności w tym i pozaesperanckiej dr. L. Zamenhofa, oceny jego dzieł w szerokim tego słowa znaczeniu.

Spośród zamenhofologów należy wymienić dla przykładu chociaż kilku: A. Holzhausa, N. Z. Maimona, R. Haupenthala, G. Waringhiena, A. Chilpieloda, J. Amoroux, U. Linsa, B. Goldena, D. Blanke, E. Borsboorna. N. Kawasaki, R. Centasi i H. Massona. Również i inni historycy opracowujący tematykę esperancką, w tym i niżej podpisana, znacznie przyczynili się do rozwoju historiografii esperanckiej. Jednakowoż za największe osiągnięcie lat ostatnich, znaczenie którego trudno przecenić, należy uznać badania i skompletowanie źródeł, których przy współpracy wybitnych badaczy ruchu esperanckiego $\mathrm{z}$ wielu krajów dokonał japoński zamenhofilog Itô Kanzi, znany pod pseudonimem „Ludoyikito”. Wydał on najpierw ośmiomiotomową, zbeletryzowaną biografię L. Zamenhofa (w sumie ponad 5500 str.) po japońsku. Następnie od 1973 do 2004 r. opublikowal 57 tomów (nazwanych ludovikami), głównie źródeł o Zamenhofie, jego dzieł, tłumaczeń, korespondencji, różnych dokumentów, rozpraw o esperancie i ruchu oraz innej problematyki z tym ruchem i dziełem Zamenhofa związanych. Dzieła te charakteryzuje niezwykła systematyczność, pietyzm w opracowaniu źródeł (komentarze), przejrzystość w układzie tematycznym. Wzbogacają je skorowidze i tabele chronologiczne. Otwierają one możliwości wszechstronnych badań. Twórca 
tego wiekopomnego dzieła zmarł 25 kwietnia 2005 r., ale jego dzieło nadal będzie służyć dalszemu rozwojowi historiografii esperanckiej.

Warto zaznaczyć również, że historiografia esperancka ma w swoim dorobku kilka wartościowych bibliografii. W kilku krajach istnieją biblioteki i archiwa esperanckie funkcjonujące według najnowszych systemów. Do najbardziej znaczących należy zaliczyć: Esperanckie Muzeum w Wiedniu i zbiory będące w posiadaniu Universala Esperanto-Asocio w Rotterdamie. $\mathrm{Na}$ kilku uniwersytetach istnieją studia esperantologiczne. Wykłada się tu również m.in. historię ruchu esperanckiego.

Z. Romaniuk zatytułował swoją odpowiedź dr. L. C. Zaleskiemu-Zamenhofowi Najtrudniej wytlumaczyć rzeczy oczywiste. Nasuwa się pytanie, jak wytłumaczyć Z. Romaniukowi, że historia jest nauką zobowiązującą do odpowiedzialności, wszechstronnego wykształcenia, również brania pod uwagę moralnych aspektów tego, co i jak się publikuje.

Duże to i zapewne trudne zadanie dla najbliższego mu środowiska naukowego w Białymstoku. 